\section{Ihmisen ja luonnon suhde uudelleenajateltuna}

Värri, Veli-Matti (2018). Kasvatus ekokriisin aikana. Vastapaino. 186 sivua.

TEOKSESSAAN PROFESSORI VeliMatti VärrI tarttuu aiheeseen, jonka ajankohtaisuutta ei tarvitse perustella. Hallitusten välisen ilmastopaneelin (IPCC) tuottama ilmastoraportti vaatii ihmiskuntaa tekemään täyskäännöksen luonnonvarojen käytössä.

Joulukuussa 2018 tarkastettu Pariisin ilmastosopimus toistaa saman viestin mutta myös sen, että ihmisten toiminta ei muutu poliittisilla linjauksilla ja syyllistämisellä. Maailman pelastamiseksi ihmisten ja muun luonnon suhdetta on ajateltava uudestaan. Meidän kasvattajien on mietittävä, millaisia ihmisiä kasvatamme, millaiseen maailmaan, ja miten, jotta elämä maapallolla voi jatkua. Näihin kysymyksiin Värri kirjassaan paneutuu.

\section{IHMINEN PYRKII HYVÄÄN ELÄMÄÄN}

Teoksen avaa kirjoittajan pohdinta kotiseutunsa samenevasta joesta ja yhden ihmisen vaikutusmahdollisuuksien rajallisuudesta: mihin voi vaikuttaa, jos ei edes oman kotijoen kuolemaan?

Aiheensa ahdistavuudesta huolimatta Värri onnistuu kirjoittamaan optimisesti, tarttuvasti ja helppolukuisesti. Ihmisten pyrkimys hyvään elämään kuuluu ihmisluontoon, ja ihmiset kaikkialla haluavat elää elämisen arvoisessa maailmassa. Jotta tämä on mahdollista tulevaisuudessakin, meidän pitää löytää perusteita lasten, nuorten ja tulevien sukupolvien toiveikkaalle tulevaisuudelle. Filosofi Antonio Gramscia mukaillen, intellektuellin - tai kaikkien, jotka ymmärtävät maailman tilan - pessimismi on voitettava tahdon optimismilla.

Teoksen perusviesti on, että tapojemme muuttaminen elämää tuhoavista elämää suojeleviksi vaatii kasvatuksen sivistys- ja identiteettitehtävien radikaalia uudelleenmäärittelyä (s. 17). Kasvatus aikansa tuotteena on kietoutunut kunkin aikakauden ideologioihin ja merkityshorisontteihin. Kirjoittaja keskustelee näistä etenkin kanadalaisen filosofin Charles Taylorin (s. 15) sekä Suomen moraalikoodeja tarkastelleiden Risto Rinteen (s. 42-43) ja Leena Kosken (s. 39) kirjoituksiin viitaten.

Suomen koulutusjärjestelmän kehitystä ovat luonnehtineet itsenäisen Suomen alkutaipaleen jumalallisen auktoriteetin kunnioitus, toisen maailmansodan jälkeinen kansalaiskoodi ja kansakunnallinen auktoriteetti, ja lopulta peruskouluajan modernin autonomisen yksilön esiinnousu.

Viime neljännesvuosisataa leimaavat Värrin mukaan uusliberalismi ja erinomaisuuden eetos.

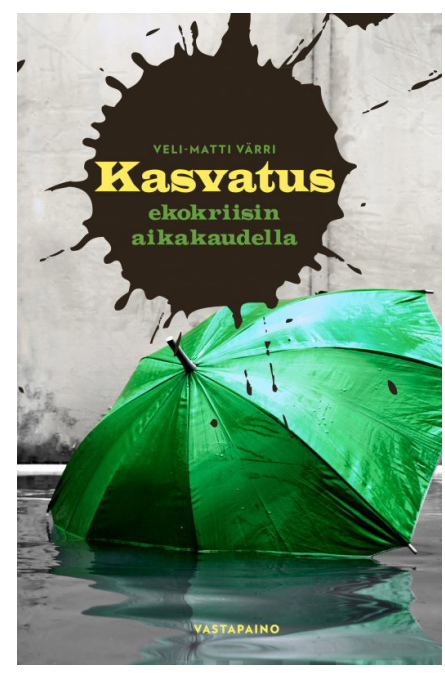

Kirjoittaja tosin huomauttaa, että uusliberalismin arvostelu ei enää ole tarpeeksi radikaalia, sillä sekä uusliberalismin että kapitalismin kääntöpuolet ovat nyt yleisesti tiedossa. Edes jatkuvan kilpailun, ylikulutuksen ja tuotemaaliman ontologian yhteydet kasvatukseen eivät vaadi selittelyä.

\section{HEDONISMI JA AHNEUS SOKAISEVAT}

Uusliberalismi on Värrin mukaan johtanut siihen, että tuotteet määrittävät elämän arvon, ja ihmisillä on ylenmääräinen hedonistinen halu aina enempään, mikä mahdollistaa "elämää ja elinkelpoista ympäristöä tuhoavan psykokapitalismin”. Ylikansalliset järjestöt, kuten Maailmanpankki, OECD ja Euroopan unioni tukevat kehitystä edistämällä kansainvälisten markkinoiden vapautta.

Päätöksenteon ja politiikan uudelleentulkinnoilla on vaikutuksensa myös kasvatuksessa. Sen tavoitteita hiotaan kasvua ja kulu- 


\section{Kasvatus muUttuU VaIn, JOS Kasvattajat ITSE PÄÄTTÄVÄT SITÄ MUUTTAA.}

tusta tukeviksi, samoin kuin ympäristön hyvin- tai pahoinvointia on opeteltu tarkastelemaan markkinoiden näkökulmasta. Näin sekä kasvatus että ympäristö valjastetaan tuotantotalouden työkaluiksi.

Peliä ei silti ole menetetty. Kasvatuksen kietoutuneisuus aikakaudelle tyypillisiin merkityshorisontteihin ja moraalikäsityksiin tarkoittaa, että vallitsevaan elämänmuotoon voidaan vielä tehdä korjausliikkeitä. Kasvatus voidaan määritellä uudelleen ekologisen sivistyksen näkökulmasta.

\section{IHMINEN ON LUONNOSTA}

Kirjan kolmannessa luvussa Värri tarkastelee kasvatusta ekokriisin kautena ontologisesta näkökulmasta etenkin fenomenologian uranuurtajan Maurice MerleauPontyn kietoutuneisuuden ajatukseen nojaten. Hän keskittyy Merleau-Pontyn 'lihan' käsitteeseen, jota vielä paremmin kuvaa englannin kielen sana flesh. Se ei ota kantaa lihan syöntiin vaan siihen, että kuten muukin liha, me ihmiset olemme peräisin luonnosta ja palaudumme luontoon. Olemme samalla jatkuvasti mieleltämme ja materialtamme kietoutuneita luontoon.

Lihan ontologia kasvatuksen ja ihmiselämän perusteena tarkoittaisi, että meidän tulisi laajentaa myötä- ja vastuuntuntoamme niin inhimilliseen kuin ei-inhimilliseenkin luontoon, johon olemme kietoutuneita. Tämä ontologia haastaa yksilökeskeisen, kilpailuun perustuvan maailman.

\section{KASVATUS LUO IHMISYYTTÄ}

Syvistä teoreettisista pohdinnoista huolimatta Värrin huoli ei ole vain teoreettinen vaan myös käytännöllinen. Hän kuvaa vakuuttavasti ja selkeästi, miten kasvatus tapahtuu yhtenä yhteiskunnan 'kokonaispraksiksen' käytänteenä, ja miten näitä käytänteitä määrittelevät kunkin historiallisen hetken ideologiat. Värrin siteeraama saksalainen kasvatustieteilijä Dietrich Benner (2005, 23) kutsuu kokonaispraksista nimellä Gesamtpraxis.

Yhteiskunnan kokonaispraksiksessa ihmiselämän perustan muodostavat jotkin yhteenkietoutuneet perusilmiöt, kuten talous, etiikka, politiikka, estetiikka, uskonto - johon liittyy ymmärrys omasta kuolevaisuudesta - ja kasvatus (32-33).

Ajatus kokonaispraksiksesta on lähellä marxilaista ajattelua. Siinä 'praksis' on mitä tahansa historiaa muuttavaa toimintaa, jolla on moraalisia, sosiaalisia ja poliittisia seurauksia kaikille, joita toiminta koskettaa (Kemmis \& Smith 2008, 4).

Kasvatus kokonaispraksiksen osana muuttaa historiaa riippumatta siitä, onko muutos kasva- tuksen tavoite. Aikakauden merkityshorisontti ja ajalle tyypilliset moraalikoodit asettavat tavoitteet, jotka eivät kuitenkaan toteudu tyhiössä ilman praksiksen muiden osien vaikutusta.

Kasvatus ei myöskään muutu ilman että kasvattajat itse päättävät sitä muuttaa. Marxia mukaillen voi todeta, että se materialistinen oppi, että ihmiset ovat olosuhteiden ja kasvatuksen tuotteita ja siis muuttuneet ihmiset ovat toisenlaisten olosuhteiden ja muuttuneen kasvatuksen tuotteita, unohtaa, että juuri ihmiset muuttavat olosuhteita ja että kasvattajan itsensä täytyy tulla kasvatetuksi.

\section{HALU OHJAA ELÄMÄÄMME}

Useimmat meistä tiedostavat sen, että ihmisellä on maailmassa erityinen vastuu ja erityisen tuhoava elämäntapa. Värri huomauttaa, että emme kuitenkaan halua toimia asian muuttamiseksi. Halun kautta voi ymmärtää elämänmuotomme ongelmallisuutta monella tasolla: se ohjaa elämäämme ideologisena, hedonistisena ja ontologisena tasona sekä olemisen puutteena. Kaikilla näillä halun tasoilla on filosofisia, pedagogisia ja poliittisia ulottuvuuksia.

Kun tarkastelemme, miten ihmisen halu sosiaalistetaan vallitsevaan ideologiseen rakenteeseen, 
voimme purkaa ja uudelleensuunnata halua. Värrin päivitys Merleau-Pontyn ajatuksiin avaa näkökulmia siihen, miten psykokapitalistiseen halun tuottamiseen ja rakenteeseen voi vaikuttaa niin, että halu muuttuu elämää suojelevaksi, "kietoutuneisuuden ontologia voisi johtaa ekologiseen sivistykseen kasvatuksessa” (s. 54).

Halu saa meidät myös "kaivautumaan onkaloon”, kun meillä on sellaisia ongelmia, joita emme halua kohdata. Onkalovertaus viittaa pyrkimykseen ratkaista ydinjäteongelma rakentamalla suomalaiseen peruskallioon maailman ensimmäistä ydinjätehautaa tulevien sadan vuoden kuluessa tuotettaville jätteille. Vaikka tiedetään, että ydinjäte on hengenvaarallista ainakin 100000 vuoden ajan, hanketta kantaa absurdi ajatus, että jätteet pysyvät harmittomina maaperässämme tulevien vuosituhansien aikana. Yhtä absurdi on ajatus, että jonkin tuleva, mystinen keksintö ratkaisee ympäristökriisimme, vaikka emme muuttaisi elintapojamme.

Etenkin halu ja nykyisen ideologian kutsu jatkuvaan edistyksen kehään ovat sidoksissa aikuiskasvatukseen. Elinikäisen oppimisen ideologia markkinaehtoineen Värrin mukaan on oivallinen esimerkki siitä, miten "edistyksen myyttiin ja teknologiseen imperatiiviin sitoutunut elämänmuoto tuottaa moraalisubjekteja” (s. 85).

Slovenialaiseen filosofiin Slavoj Žižekin ja kasvatuksen tutkimus- ja teoriatraditioita tutkineeseen Antti Saareen viitaten Värri kirjoittaa, että ihminen ha- lusubjektina ei tule koskaan ehyeksi ideologisessa nautinnon kehässä, koska meitä luonnehtivat ikuinen puute ja keskeneräisyys, mistä seuraa, että koko elämää määrittää liikevoima. On osattava enemmän, tehtävä enemmän ja omistettava enemmän.

\section{ONKALOISTA PÄÄSEE POIS}

Elinikäisen oppimisen ja kapitalismin logiikka kietoutuvat toisiinsa: jatkuvan kouluttautumisen tarve luo mielikuvaa ihmisestä vajaana (s. 88). Kun kukaan ei tiedä, mitä taitoja tulevaisuudessa tarvitaan esimerkiksi työmarkkinoilla, oppija ei tule koskaan valmiiksi. Tätä kriittisen pedagogiikan ydinajatusta on vaikea kyseenalaistaa, mutta sitä on hyvä tarkastella kulutuksen ja halun näkökulmasta. Kapitalismi perustuu ikuiseen puutteen kultivointiin tuottamalla uusia ongelmia ja niihin sopivia, lisää kulutusta vaativia ratkaisuja. Tämä ajatus on harvoin sopusoinnussa luonnon kantokyvyn kanssa.

Teos ei syyllistä vaan antaa toivoa. Viimeiset luvut on omistettu ihmiskunnan viisaudelle ja yhteisen tilanteemme toiveikkuudelle. Onkalosta pääsee pois, kasvatuksella voi muuttaa maailmaa, ja on pidettävä kiinni siitä, mikä ihmisessä on parasta. Kasvattajina voimme auttaa tunnistamaan aikakautemme merkityshorisontin kestämättömyyden ja puuttumaan ajallemme tyypillisiin, tuhoisiin käytänteisiin. Maailmaa muuttavan, kriittisen pedagogin on oltava valmis käymään hege- moniakamppailua siitä, mikä on "välttämätöntä" tai "luonnollista" (s. 142), ja mikä tekee kasvatuksesta hyvää (s.108). Ihmiselämälle ainutlaatuiset uudistumiskyky ja käytännön viisaus voivat saada maailman uusille raiteille.

Veli-Matti Värrin esittämät kysymykset ovat globaaleja ja tärkeitä kaikilla kasvatuksen kentillä. Kirja on suunnattu kasvattajille, opettajille ja kasvatusalan tutkijoille. Sen soisi löytävän paikkansa etenkin kasvatustieteiden opinnoissa. Teos on vähintään ajatuksia herättävä, toivottavasti myös kasvatusta ja maailmaa muuttava. Marxin (1895) sanoin: Filosofit ovat vain eri tavoin selittäneet maailmaa, mutta tehtävänä on sen muuttaminen. Sama pätee kasvattajiin.

\section{MERVI KAUKKO}

$K T$, lehtori

Monash University, Melbourne tutkijatohtori

Institute of Advanced Social

Research, Tampereen yliopisto

\section{LÄHTEET}

Kemmis, S. \& Smith, T. (2008) Praxis and Praxis Development. Teoksessa

Kemmis, S. \& Smith, T. (eds.) Enabling Praxis: Challenges for Education, 3-13. Rotterdam: Sense Publishing.

Marx, K. (1895 / 1978) Teesejä Feuerbachista. Teoksessa MarxEngels. Valitut teokset, 2. osa. Moskova: Kustannusliike Edistys, 63-66. https://www.marxists.org/ suomi/marx-engels/1845/teesejafeuerbachista.htm. 